\title{
COMPATIBILITY OF BIODIESEL FUEL WITH METALS AND ELASTOMERS IN FUEL DELIVERY SYSTEM OF A DIESEL ENGINE
}

\author{
DAVANNENDRAN CHANDRAN*; NG HOON KIAT*; HARRISON LAU LIK NANG**; GAN SUYIN*; \\ CHOO, Y M ${ }^{* *}$ and SALMAH JAHIS**
}

\begin{abstract}
This article intends to evaluate available literature findings and determine if they are representative of the actual compatibility between fuel delivery materials (FDM) and biodiesel fuel in the physical system. The study will also evaluate current test standards on their effectiveness of representing the physical fuel delivery system. Although the compatibility of a number of materials with biodiesel fuel has been reported, there is a need to establish the exact materials present in the fuel delivery system. This is especially true for elastomers since their resistance is mainly dependent on their elemental compositions. While typical standards such as the ASTM G31 and ASTM D471 for metals and elastomers, respectively are deemed suitable for evaluating the effects of water content, total acid number and oxidised products in biodiesel on FDM degradation based on laboratory immersion studies, none of these standards resemble the actual engine operating conditions such as varying fuel pressure/temperature as well as presence of a wide range of materials in a typical diesel engine's fuel delivery system. As such, findings from existing studies so far are inadequate to conclusively determine the compatibility between FDM and biodiesel fuel in the actual fuel delivery system of a diesel engine.
\end{abstract}

Keywords: biodiesel compatibility, fuel delivery materials (FDM), actual operating conditions, material composition in fuel line.

Date received: 16 December 2014; Sent for revision: 2 July 2015; Received in final form: 4 December 2015; Accepted: 13 January 2016.

\section{INTRODUCTION}

Biodiesel (B100), also known as fatty acid methyl ester (FAME), is typically produced from vegetable (or animal) oil through the transesterification process. Under transesterification, vegetable oil molecules which consist of triglycerides are converted into three mono-alkyl esters, as shown

\footnotetext{
* Faculty of Engineering, University of Nottingham Malaysia Campus, Jalan Broga, 43500 Semenyih, Selangor, Malaysia. E-mail: hoonkiat.ng@nottingham.edu.my

** Malaysian Palm Oil Board, 6 Persiaran Institusi, Bandar Baru Bangi, 43000 Kajang, Selangor, Malaysia.
}

in Figure 1. The main purpose of this process is to reduce the high viscosity of vegetable oil $\left(40 \mathrm{~mm}^{2}\right.$ $\mathrm{s}^{-1}$ ) to a much lower viscosity of approximately 5 $\mathrm{mm}^{2} \mathrm{~s}^{-1}$, to be suitable for diesel engine operation. To date, biodiesel is becoming an important alternative fuel in the global fuel market due to factors such as declining air quality, depleting energy reserves and price hike in fossil fuel. Furthermore, its ability to be used without general engine and infrastructure modification promotes its adoption level.

Utilisation of biodiesel was initiated in blended form with diesel, from a minimum of 1 vol\% biodiesel. Today, the blending level has reached a maximum of $20 \mathrm{vol} \%$ of biodiesel in diesel (B20), as 


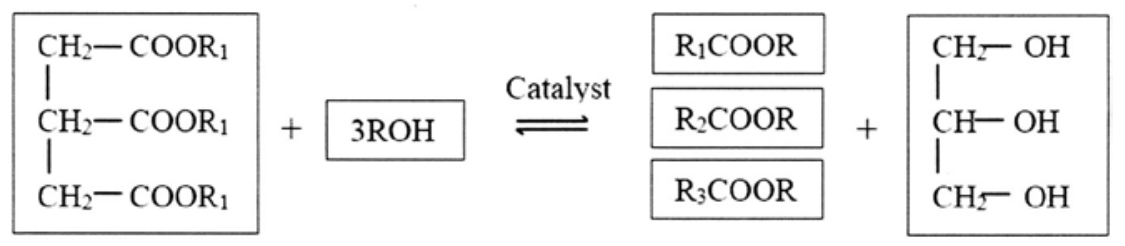

Figure 1. Transesterification process for biodiesel production from vegetable oil.

shown in Table 1. The B100 and B20 fuels here are typically expected to meet the specifications as per stipulated in the ASTM 6751-15a (ASTM D6751-15a, 2015) and the ASTM D7467-15a (ASTM D7467-15a, 2015) Standards, respectively. However, the use beyond B20 is typically not allowed as the level of FDM degradation becomes too severe. Other challenges include reduced lifespan of fuel delivery components such as filter, pump and injector, wax formation, sedimentation, poor atomization and injector choking ( $\mathrm{Ng}$ et al., 2010; Van Gerpen et al., 2007; Mofijur et al., 2013).

The fuel delivery and storage system in a diesel engine typically consists of the fuel tank, fuel lines, fuel filter, fuel pump, fuel rail and fuel injectors as shown in Figure 2. The typical metals and elastomers present in the fuel delivery system are listed in Table 2. Metals were chosen due to their excellent compatibility with diesel, as well as for their suitability in the fabrication of fuel delivery components. The components are expected to last for an estimated lifespan of 10-15 years, depending on their function. Corrosion, a natural phenomenon of metal mass loss could reduce the lifespan. High corrosion rate would result in an accelerated metal mass loss leading to fuel leakage. Fuel leakage, critically between the fuel filter and the fuel pump, would result in fuel starvation. This phenomenon, could lead to fuel pump seizing, abruptly stalling the engine operation. Like metals, the compatibility of elastomers has long been established with diesel. The utilisation of incompatible fuel could however accelerate the degradation process, leading to significantly early failure. This could be observed in the form of seal breakage and hose rupture, culminating in fuel leakage and loss of compression.

Realising these implications, extensive studies have been conducted on the compatibility of biodiesel with FDM. Here, greater metal corrosion with biodiesel than diesel fuel have been reported (Kaul et al., 2007; Geller et al., 2008; Sgroi et al., 2005). The addition of even a small amount of biodiesel in diesel blend such as $2 \mathrm{vol} \%$ in terne cups at $80^{\circ} \mathrm{C}$ for $1000 \mathrm{hr}$ increased the leaching of lead by 22 900\% when compared with diesel (Tsuchiya et al., 2006). The corrosion rate is reported to increase with increasing biodiesel concentration in diesel (Haseeb et al., 2010a). The rise in copper corrosion rate in biodiesel when compared to diesel is typically within the range of $68 \%$ to $148 \%$ (Haseeb et al., 2010a; Fazal et al., 2010; 2012). The utilisation of corrosion inhibitors in controlling metal corrosion, despite being effective (Fazal et al., 2011b; Kalam and Masjuki, 2002), is not suitable since it adversely affects elastomers by inducing further crosslinks (Petrash, 2002). In addition, leached metal ions due to corrosion could adversely affect biodiesel's stability. These ions, acting as catalyst in promoting biodiesel oxidation, form undesirable oxidised products such as aldehydes and ketones (Sarin et al., 2009a, b;

TABLE 1. LEVEL OF BIODIESEL ADOPTION IN SELECTED COUNTRIES/REGIONS

\begin{tabular}{lll}
\hline \multicolumn{1}{c}{ Nation } & \multicolumn{1}{c}{ Current utilisation } & \multicolumn{1}{c}{ Future target } \\
\hline Australia & B5-B20 ('Biodiesel in Australia,' 2014) & B20-B100 ('Biodiesel in Australia,' 2014) \\
Brazil & B5 (Rodrigues, 2009) & B7 (Lima, 2013) \\
Ecuador & B5 (Lane, 2013) & B10 (Lane, 2013) \\
Peru & B2 (Lane, 2013) & B5 (Lane, 2013) \\
Uruguay & B2 (Lane, 2013) & B5 (Lane, 2013) \\
United States & B10 (Lane, 2013) & B20 (Lane, 2013) \\
European Union & B5.75 (Lane, 2013) & B10 (Lane, 2013) \\
Malaysia & B7 (Zainal, 2014) & B10 (Adnan, 2013) \\
Philippines & B2 (Lane, 2013) & B5 (Lane, 2013) \\
South Korea & B2 (Lane, 2013) & B3 (Lane, 2013) \\
\hline
\end{tabular}




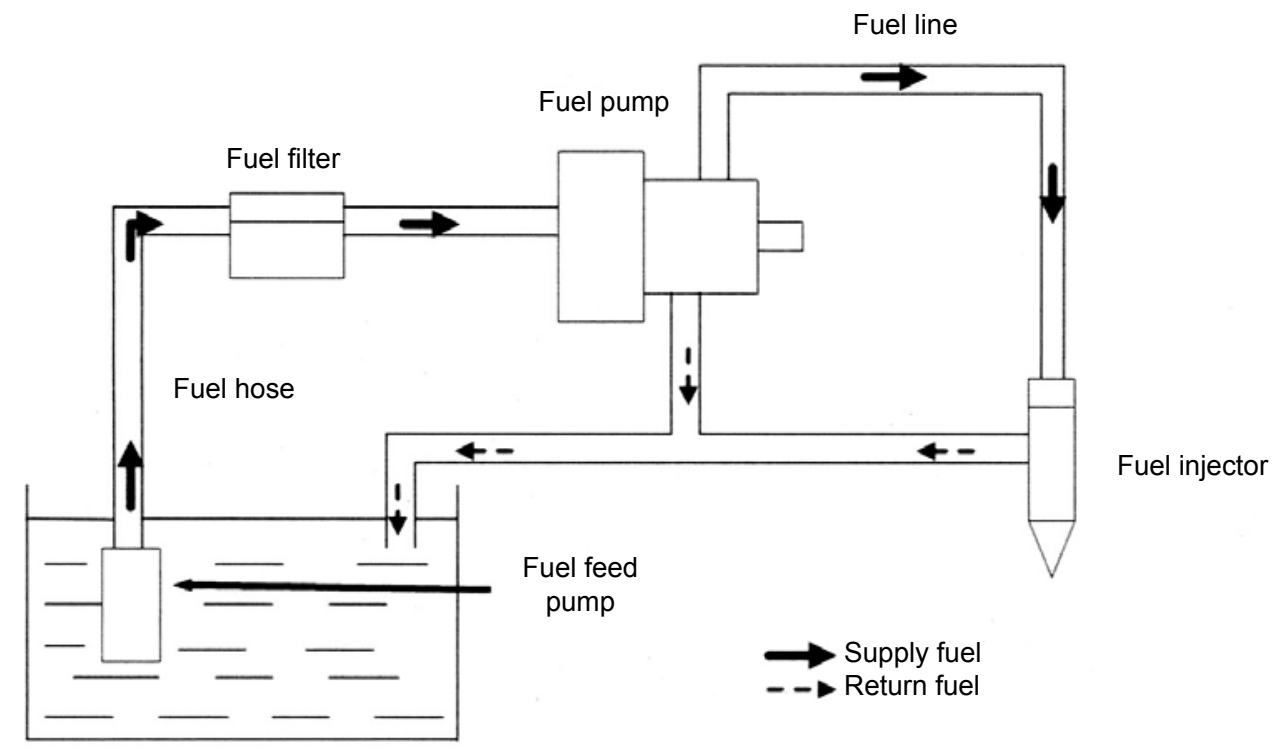

Figure 2. Fuel delivery system in a typical diesel engine.

TABLE 2. MATERIALS USED FOR THE FABRICATION OF FUEL STORAGE AND DELIVERY COMPONENTS

\begin{tabular}{ll}
\hline \multicolumn{1}{c}{ Parts } & \multicolumn{1}{c}{ Materials } \\
\hline Fuel tank & Steel, plastic \\
Fuel feed pump & Aluminum alloy, iron-based alloy, copper-based alloy \\
Fuel lines & Steel, plastic, rubber \\
Fuel filter & Aluminum, plastic, paper, resin impregnated paper \\
Fuel pump & Aluminum alloy, iron-based alloy, copper-based alloy \\
Fuel injector & Stainless steel \\
Nozzles & Steel \\
Gasket & Elastomer, paper, cork, copper \\
\hline
\end{tabular}

Source: Abstracted from Yamagata (2005), Crouse and Anglin (1993), Bosch (2001), Haseeb et al. (2011a), Sorate and Bhale (2013).

Haseeb et al., 2011a). Oxidised biodiesel is reported to be more corrosive than un-oxidised biodiesel (Haseeb et al., 2010a). The corrosion rate of copper was found to increase by $59 \%$ when comparison was made between oxidised and un-oxidised palm biodiesel at $80^{\circ} \mathrm{C}$ for $840 \mathrm{hr}$ of immersion.

Most of the elastomers which showed good compatibility with diesel fuel underwent significant degradation when tested with biodiesel fuel (Haseeb et al., 2010b; Zhang et al., 2009; Bessee and Fey, 1997). In a study by Hu et al. (2010) the authors determined the mass change of nitrile rubber immersed in diesel and Jatropha curcas biodiesel for $672 \mathrm{hr}$ at $26^{\circ} \mathrm{C}$. Here, the mass change was reported to be $250 \%$ higher in Jatropha curcas biodiesel than in diesel. In a separate study by Haseeb et al. (2011b) to evaluate the compatibility of poly-tetrafluoroethylene in diesel and palm biodiesel for $1000 \mathrm{hr}$ at $26^{\circ} \mathrm{C}$, the volume change of poly-tetrafluoroethylene was reported to be three times higher in palm biodiesel than in diesel. In general, carbon black and silica fillers serve to improve the hardness, abrasion resistance, tensile strength and tear strength properties of elastomers (Haseeb et al., 2010b). The addition of curing agents and accelerators creates cross-links between the polymer chains. The reaction caused by biodiesel fuel on the polymer chain, cross-links and filler system have been suggested as a cause of degradation to the elastomers (Haseeb et al., 2010b).

Majority of the studies agreed that FDM experienced greater degradation than the acceptable level with B20 and above. However, these studies were not investigated under actual diesel engine's fuel delivery system. Instead, a majority of the studies utilised immersion investigation such as the ASTM G31 and ASTM D471 for metal and elastomer, 
respectively. For metals, the mass loss is determined to calculate the corrosion rate. On the other hand, the degradation of elastomer is determined from volume, mass, tensile strength and hardness change. In terms of the samples preparation, ASTM G1 (ASTM G1-03, 2011) and ASTM D471 (ASTM D471-12, 2012) are usually employed for metal and elastomer specimens, respectively. Findings from these studies were utilised to assess the compatibility of FDM with biodiesel to determine the permissible biodiesel-diesel blend for utilisation (Singh et al., 2012; Haseeb et al., 2011a; Zuleta et al., 2012). Despite the significance of the findings, it is crucial to ensure the accuracy of existing compatibility studies in representing the compatibility of FDM with biodiesel fuel in the physical system. Accurate representation is necessary as it leads to accurate judgement which directly affects the allowable biodiesel-diesel blends for general utilisation in diesel engines. This review aims to evaluate the sufficiency of existing studies on assessing the compatibility of FDM with biodiesel in the actual fuel delivery system of a diesel engine. The focused aspects are the evaluated FDM and the standards utilised for the compatibility studies.

\section{EVALUATED MATERIALS IN EXISTING COMPATIBILITY STUDIES}

A number of studies have evaluated the compatibility of metals and elastomers with biodiesel, diesel as well as biodiesel-diesel blends. Table 3 shows the list of evaluated metals and elastomers. The majority of the studies agreed that copper and nitrile rubber are the most adversely affected metal and elastomer respectively, while stainless steel, aluminium and fluoroelastomer are the least (Meenakshi et al., 2013; Geller et al., 2008; Bessee and Fey, 1997; Zhang et al., 2009; Haseeb et al., 2011a; McCormick and Terry, 2006). An important point observed from these studies is that none investigated the exact materials present in the fuel delivery system prior to the study. Typical approach of evaluating common FDM such as those listed in handbooks (Crouse and Anglin, 1993; Yamagata, 2005) might not be sufficient as the compatibility of materials with fuels are very dependent on their elemental composition.

Determination of the exact material composition in fuel line is essential especially for elastomers as the chemical resistance is dependent on their elemental compositions. For example, higher percentage of acrylonitrile content in nitrile rubber contributes towards its higher resistance against fuel permeation/attack. In a study by Linhares et al. (2013), the authors evaluated the effects of coconutbased biodiesel on nitrile rubber with $28 \%$ and $45 \%$ acrylonitrile content. Here, the nitrile rubber with $28 \%$ acrylonitrile content experienced $90 \%$ reduction in tensile strength while the latter experienced only
$10 \%$ reduction. Similarly, higher fluorine content in fluoroelastomers contributes towards the higher resistance against fuel permeation/attack. To date, the least resistant fluoroelastomer evaluated in biodiesel has $64 \%$ fluorine content by weight (Thomas et al., 2007). Based on this, biodiesel is said to have sufficient compatibility with fluoroelastomer only if the existing fluoroelastomer has a minimum fluorine content of $64 \mathrm{wt} . \%$. Furthermore, since common rail direct injection is the current mainstream fuel delivery system, emphasis should be placed towards the fuel delivery materials of this particular set-up.

\section{STANDARDS USED IN EXISTING COMPATIBILITY STUDIES}

To date, there are two analytical tests to determine the fuel's corrosive effect on metals: the ASTM D130 and ASTM D664. ASTM D130 (ASTM D13012,2012 ) evaluates the effects of immersed copper strip in fuel, with a standardised reference strip. The results are rated on a scale of slight tarnish $1 \mathrm{~A}, \mathrm{~B}$ to heavy tarnish $4 \mathrm{~A}-\mathrm{C}$. Table 4 shows the experimental results conducted based on the ASTM D130. The $1 \mathrm{~A}$ result (marginal corrosion) was obtained for all the tested samples, irrespective of diesel, biodiesel [from cottonseed methyl ester (CME), rapeseed methyl ester (RME) and soya methyl ester (SME)] and B20 biodiesel-diesel blend. This demonstrates that the analytical test is incapable of distinguishing the corrosive effects of diesel, biodiesel, biodieseldiesel blends as well as different biodiesel feedstock towards copper (Haseeb et al., 2011a). Nevertheless, the test determines the corrosivity of the fuel based on the quantity of sulphur compound present (ASTM D130-12, 2012). Since biodiesel does not contain sulphur, this test is not able to measure its corrosivity.

ASTM D664 (ASTM D664-11, 2011) is the other analytical test utilised to determine the fuel's corrosive effect on metal. This test works by determining the required mass of bases solution (potassium hydroxide) in neutralising the acidity of the fuel. The acidity of the fuel could typically be correlated to the fuel's corrosivity. However, there is no general correlation between the acid number and the corrosive tendency of the biodiesel (ASTM D66411, 2011). The varying corrosivity of the oxidation products and the organic acids which are naturally present in biodiesel fuels are believed to be the key parameters governing this observation. Therefore, this analytical test is also deemed unsuitable to determine the corrosion effect of biodiesel and biodiesel-diesel blends.

Apart from these two analytical tests, a number of standards have been utilised in evaluating the compatibility between biodiesel and metals. Among these are the immersion standard ASTM G31 (ASTM 
TABLE 3. EVALUATED FUEL DELIVERY MATERIALS AND THE CORRESPONDING STUDIES IN LITERATURE

\begin{tabular}{|c|c|}
\hline & Metals \\
\hline Type & Studies (Ref.) \\
\hline Aluminium & $\begin{array}{l}\text { Fazal et al. (2010; 2012), Norouzi et al. (2012), Anisha et al. (2011), Hu et al. (2012), Chew et al. } \\
\text { (2013), Meenakshi et al. (2011) }\end{array}$ \\
\hline Brass & Fazal et al. (2012), Aquino et al. (2012), Anisha et al. (2011), Meenakshi et al. (2011; 2013) \\
\hline Bronze & Haseeb et al. (2010a) \\
\hline Carbon steel & $\begin{array}{l}\text { Fazal et al. (2011a), Maru et al. (2009), Anisha et al. (2011), Hu et al. (2012), Liu and Fang (2009), } \\
\text { Grainawi et al. (2008), Meenakshi et al. (2011), Cursaru and Mihai (2012), Fernandes et al. (2013) }\end{array}$ \\
\hline Cast iron & Fazal et al. $(2012 ; 2011 b)$ \\
\hline Copper & $\begin{array}{l}\text { Haseeb et al. (2010a), Fazal et al. (2010; 2012; 2013), Aquino et al. (2012), Norouzi et al. (2012), } \\
\text { Anisha et al. (2011), Hu et al. (2012), Meenakshi et al. (2011; 2013) }\end{array}$ \\
\hline Galvanized steel & Fernandes et al. (2013) \\
\hline Magnesium & Chew et al. (2013) \\
\hline Monel steel & Cursaru and Mihai (2012) \\
\hline \multirow[t]{2}{*}{ Stainless steel } & Fazal et al. (2010), Hu et al. (2012), Cursaru and Mihai (2012) \\
\hline & Elastomers \\
\hline Type & Studies (Ref.) \\
\hline Acrylic rubber & Trakarnpruk and Porntangjitlikit (2008) \\
\hline Chloroprene & Haseeb et al. (2011b) \\
\hline $\begin{array}{l}\text { Ethylene-propylene-diene } \\
\text { monomer }\end{array}$ & Hu et al. (2010), Zhang et al. (2009), Haseeb et al. (2011b) \\
\hline Fluoroelastomer & $\begin{array}{l}\text { Thomas et al. (2007), Hu et al. (2010), Micallef (2009), Zhang et al. (2009), McCormick and Terry } \\
\text { (2006), Trakarnpruk and Porntangjitlikit (2008), Haseeb et al. (2010b) }\end{array}$ \\
\hline Fluorosilicone & Micallef (2009) \\
\hline Hydrogenated nitrile rubber & McCormick and Terry (2006), Trakarnpruk and Porntangjitlikit (2008) \\
\hline Nitrile rubber & $\begin{array}{l}\text { Hu et al. (2010), Zhang et al. (2009), McCormick and Terry (2006), Linhares et al. (2013), } \\
\text { Trakarnpruk and Porntangitlikit (2008), Haseeb et al. (2010b; 2011b) }\end{array}$ \\
\hline Nylon & Choudhury and Mallick (2012) \\
\hline Polychloroprene & Haseeb et al. (2010b) \\
\hline Poly-tetrafluoroethylene & Haseeb et al. (2011b) \\
\hline Synthetic rubber & Zhang et al. (2009) \\
\hline Silicone rubber & Haseeb et al. (2011b), Zhang et al. (2009) \\
\hline
\end{tabular}

G31-12a, 2012), rotating cage standard ASTM G184 (ASTM G184-12, 2012) and the linear polarisation resistance standard ASTM G59 (ASTM G59-97, 2014). Table 5 describes the working principle of these standards and the respective studies based of these. Typically, metal deterioration is evident from mass loss. Therefore, the analysis which is given the most importance is corrosion rate.

The major difference between ASTM G31 and ASTM G184 is the flow condition. In ASTM G31, the fuel is in static condition while the fuel is travelling at a fixed speed in ASTM G184. Meenakshi et al. (2013) compared the corrosion rates of copper in Pongamia pinnata oil under ASTM G31 and ASTM
G184 test standards for $100 \mathrm{hr}$ at a rotational speed of 500 revolution per minute. The authors reported higher corrosion rate of copper by 12 times under ASTM G184 than ASTM G31. As such, higher metal corrosion is anticipated when the fuel travels through the fuel delivery system than when stored in the fuel tank. In terms of the ASTM G31 and ASTM G59, the earlier measures the duration averaged corrosion rate, while the latter measures the instantaneous corrosion rate. In a study by Anisha et al. (2011) the corrosion rate of copper, brass and carbon steel were compared under ASTM G31 and ASTM G59 test standards. Here, higher corrosion rate were reported under ASTM G31 than ASTM G59 for 
TABLE 4. RESULTS OF BIODIESEL'S CORROSIVENESS FROM ASTM D130 AND ISO 2160 STANDARDS

\begin{tabular}{lllc}
\hline \multicolumn{1}{c}{ References } & \multicolumn{1}{c}{ Standard } & \multicolumn{1}{c}{ Fuel } & Results \\
\hline Barnitt et al. (2006) & ASTM D130 & Diesel & 1A \\
Mazzoleni et al. (2007) & ASTM D130 & B20 (feedstock not mentioned) & 1A \\
& & B100 (feedstock not mentioned) & 1A \\
Rashid et al. (2009) & ASTM D130 & B100 (CME) & $1 \mathrm{~A}$ \\
McCormick and Terry (2006) $)$ & ASTM D130 & B20 ( SME; oxidised) & $1 \mathrm{~A}$ \\
Dinkov et al. (2009) & ISO 2160 & B100 (RME) & $1 \mathrm{~A}$ \\
& (ISO 2160:1998) & & $1 \mathrm{~A}$ \\
Clark et al. (1984) & ASTM D130 & B100 (SME) & $1 \mathrm{~A}$ \\
\hline
\end{tabular}

Source: Abstracted from Haseeb et al. (2011a).

TABLE 5. WORKING PRINCIPLES OF THE TEST STANDARDS AND THE CORRESPONDING REFERENCE STUDIES

\begin{tabular}{cll}
\hline Standards & \multicolumn{1}{c}{ Working principle } & \multicolumn{1}{c}{ References } \\
\hline ASTM G31 & $\begin{array}{l}\text { Determines the average corrosion rate by accelerating the metal } \\
\text { deterioration by simulating the conditions of interest through } \\
\text { immersion study (typically static) }\end{array}$ & $\begin{array}{l}\text { Chew et al. ( 2013), Haseeb et al. (2010a), Fazal } \\
\text { et }(2011 \mathrm{a})\end{array}$ \\
ASTM G184 & $\begin{array}{l}\text { Determines the corrosion rate by simulating pipeline flow } \\
\text { under laboratory conditions (dynamic) }\end{array}$ & Meenakshi et al. (2013) \\
ASTM G59 & $\begin{array}{l}\text { Determines the corrosion rate by monitoring the relationship } \\
\text { between the electrochemical potential and current generated } \\
\text { between electrically charged electrodes }\end{array}$ & Anisha et al. (2011) \\
ASTM D471 & $\begin{array}{l}\text { Determines the effects on elastomers by accelerating the } \\
\text { elastomer degradation by simulating the conditions of interest }\end{array}$ & $\begin{array}{l}\text { Thomas et al. (2007), McCormick and Terry, } \\
(2006) \text {, Haseeb et al. (2010b) }\end{array}$ \\
\hline
\end{tabular}

copper, brass and carbon steel by $698 \%, 262 \%$ and $426 \%$, respectively. The higher corrosion rate under ASTM G31 than ASTM G59 nevertheless shows that the corrosion rate of metals in biodiesel increases with duration.

The most commonly utilised standard for the elastomers is the immersion standard ASTM D471 (ASTM D471-12, 2012). The working principle of this standard and the respective studies utilised this are shown in Table 5. ASTM D471 and ASTM G31 are similar in a way where both standards accelerate the material deterioration process by simulating the conditions of interest in evaluating the effects on the materials. Among the commonly evaluated conditions of interest include the effects of water content, total acid number and oxidised products present in biodiesel fuels on FDM degradation. For example, Haseeb et al. (2010a) utilised ASTM G31 to evaluate the effects of oxidised products present in palm biodiesel on copper's corrosion rate immersed at $60^{\circ} \mathrm{C}$ for $840 \mathrm{hr}$. In another study, McCormick and Terry (2006) utilised ASTM D471 to evaluate the effects of oxidised products present in B20 SME on nitrile rubber's degradation immersed at $60^{\circ} \mathrm{C}$ for 1000 hr.
All these standards are excellent in benchmarking the effects of biodiesel, diesel and biodieseldiesel blends on FDM. However, the conditions employed in these standards do not resemble the actual operating conditions in the fuel delivery system of diesel engines. The conditions in the fuel delivery system are dependent on the varying speed-load, which instantaneously alters the fuel pressure and hence, directly affects the fuel temperature. The effects of varying fuel temperature, together with the presence of a variety of FDM, could not be simulated by any of these standards. As a result, the identified factors promoting material degradation such as water content, total acid number and oxidised products determined from these standards may not necessarily be present in the actual fuel delivery system.

Besides, there is also a possibility that the adverse effects observed on FDM especially using the immersion test could be influenced by secondary effects. The secondary effects here refer to the effects caused by the formed oxidation products such as aldehydes, ketones and short chain acids. The presence of these products is known to accelerate the FDM deterioration (Haseeb et al., 2010a). 


\section{CONCLUSION}

Based on the discussion above, the existing studies are deemed insufficient to comprehensively assess the compatibility of FDM in the fuel delivery system of a diesel engine with biodiesel fuel. This is mainly due to the lack of available studies in investigating the exact FDM present in the physical fuel delivery system. This is important as the elemental composition present in the FDM, especially elastomer, significantly determines the resistance towards biodiesel fuel. Furthermore, the current standards used in evaluating the compatibility between FDM and biodiesel do not resemble the actual conditions in the fuel delivery system in a typical diesel engine. This is especially true in terms of the varying fuel pressure/temperature and the various materials present in the fuel delivery system.

The identified factors promoting material deterioration from these studies may not necessarily be present under the actual operating conditions. Besides, there are also chances for the formed oxidation products to be influencing the findings observed mainly from immersion studies. All these suggest that a more systematic study is required to appropriately appraise the compatibility between the FDM and biodiesel fuel in the fuel delivery system.

Firstly, the exact materials present in the fuel delivery system should be systematically determined. This includes elemental composition for both metals and elastomers. Additional tests would be required for elastomers such as functional group determination to allow for the exact material identification. Here, FDM of the common rail fuel injection system should be given emphasis due to its popularity as the current mainstream fuel delivery set-up. Secondly, the deterioration of biodiesel under diesel engine operations, preferably common rail system should be determined. This is crucial in order to understand if biodiesel fuels actually oxidise under actual diesel engine operations, as well as to ascertain the presence of common factors promoting FDM degradation such as water content and total acid number. From here, the effects of oxidised biodiesel, water and total acid number on FDM degradation could be determined.

In conclusion, the compatibility of FDM with biodiesel in the actual fuel delivery system of a diesel engine could be sufficiently assessed only with the availability of all the identified information.

\section{ACKNOWLEDGEMENT}

The authors would like to acknowledge the financial and facilities support provided by MPOB and the Faculty of Engineering, University of Nottingham Malaysia Campus for this research work.

\section{REFERENCES}

ADNAN, H (2013). Malaysia's B10 biodiesel programme and its benefits. The Star Online, 12.

ANISHA, A; MEENAKSHI, $\mathrm{H}$ and SHYAMALA, $\mathrm{R}$ (2011). Study on the impact of Jatropha curcus biodiesel on selected metals. The Ecoscan, 1: 291-294. http: / / theecoscan.in/journalpdf/spl2011_v1-49\%20anisha\%20anand.pdf

AMERICAN SOCIETY TESTING and MATERIAL (ASTM) D130-12 (2012). Standard test method for corrosiveness to copper from petroleum products by copper strip test. Annual Book of ASTM Standards. DOI:10.1520/D0130-12.

AMERICAN SOCIETY TESTING and MATERIAL (ASTM) D471-12 (2012). Standard test method for rubber property-effect of liquids. Annual Book of ASTM Standards. DOI:10.1520/D0471-12A.

AMERICAN SOCIETY TESTING and MATERIAL (ASTM) D664-11 (2011). Standard test method for acid number of petroleum products by potentiometric titration. Annual Book of ASTM Standards. DOI:10.1520/D0664-11A.

AMERICAN SOCIETY TESTING and MATERIAL (ASTM) D6751-15a (2015). Standard specification for biodiesel fuel blend stock (b100) for middle distillate fuels. Annual Book of ASTM Standards. DOI:10.1520/ D6751-15A.

AMERICAN SOCIETY TESTING and MATERIAL (ASTM) D7467-15a (2015). Standard specification for diesel fuel oil, bioidesel blend (B6 to B20). Annual Book of ASTM Standards.DOI:10.1520/D7467-15A.

AMERICAN SOCIETY TESTING and MATERIAL (ASTM) G1-03 (2011). Standard practice for preparing, cleaning, and evaluating corrosion test specimens. Annual Book of ASTM Standards. DOI:10.1520/G0001-03R11.

AMERICAN SOCIETY TESTING and MATERIAL (ASTM) G31-12a (2012). Standard guide for laboratory immersion corrosion testing of metals. Annual Book of ASTM Standards. DOI:10.1520/ G0031-12A.

AMERICAN SOCIETY TESTING and MATERIAL (ASTM) G59-97 (2014). Standard test method for conducting potentiodynamic polarization resistance measurements. Annual Book of ASTM Standards. DOI:10.1520/G0059.

AMERICAN SOCIETY TESTING and MATERIAL (ASTM) G184-12 (2012). Standard practice for 
evaluating and qualifying oil field and refiney corrosion inhibitors using rotating cage. Annual Book of ASTM Standards. DOI:10.1520/G0184-06R12.

AQUINO, I P; HERNANDEZ, R P B; CHICOMA, D L; PINTO, H P F and AOKI, I V (2012). Influence of light, temperature and metallic ions on biodiesel degradation and corrosiveness to copper and brass. Fuel, 102: 795-807. DOI:10.1016/j.fuel.2012.06.011.

BARNITT, R; HAYES, R R; RATCLIFF, M; MCCORMICK, R L; HA, L and FANG, H L (2006). 100,000-Mile evaluation of transit buses operated on biodiesel blends (B20) (No. 2006-01-3253). SAE Technical Paper. DOI:10.4271/2006-01-3253.

BESSEE, G B and FEY, J P (1997). Compatibility of elastomers and metals in biodiesel fuel blends (No. 971690). SAE Technical Paper. DOI:10.4271/971690.

BIODIESEL IN AUSTRALIA (2014). Biofuels Association of Australia. http://biofuelsassociation. com.au/biodiesel-in-australia, accessed on 4 January 2014.

BOSCH, V (2001). Endurance test with E diesel. Internal Report No. 00/47/3156. Robert Bosch Corporation, Farmington Hills, MI, USA.

CHEW, K V; HASEEB, A S M A; MASJUKI, H H; FAZAL, M A and GUPTA, M (2013). Corrosion of magnesium and aluminum in palm biodiesel: a comparative evaluation. Energy, 57: 478-483. DOI:10.1016/j.energy.2013.04.067.

CHOUDHURY, P S and MALLICK, P (2012). Effect of biodiesel on the tensile properties of nylon-6 (No. 2012-01-0752). SAE Technical Paper. DOI:10.4271/2012-01-0752.

CLARK, S; WAGNER, L; SCHROCK, $\mathrm{M}$ and PIENNAAR, P (1984). Methyl and ethyl soybean esters as renewable fuels for diesel engines. J. Amer. Oil Chem. Soc., 61: 1632-1638. DOI:10.1007/ BF02541648.

CROUSE, W and ANGLIN, D (1993). Automotive Mechanics. https://books.google.co.in/books/about/ Automotive_Mechanics.html?id=lzkeaaaacaaj

CURSARU, D and MIHAI, S (2012). Corrosion behaviour of automotive materials in biodiesel from sunflower oil. Revista De chimie, 63: 945-948. http:/ / www.revistadechimie.ro/pdf/CURSARU\% $20 \mathrm{D}$. pdf $\% 209 \% 2012$.pdf

DINKOV, R; HRISTOV, G; STRATIEV, D and BOYNOVA ALDAYRI, V (2009). Effect of commercially available antioxidants over biodiesel/diesel blends stability. Fuel, 88: 732-737. DOI:10.1016/j.fuel.2008.09.017.

FAZAL, M A; HASEEB, A S M A and MASJUKI, $H$ (2010). Comparative corrosive characteristics of petroleum diesel and palm biodiesel for automotive materials. Fuel Processing Technology, 91: 1308-1315. DOI:10.1016/j.fuproc.2010.04.016.

FAZAL, M A; HASEEB, A S M A and MASJUKI, $H$ (2011a). Effect of temperature on the corrosion behavior of mild steel upon exposure to palm biodiesel. Energy, 36: 3328-3334. DOI:10.1016/j. energy.2011.03.028.

FAZAL, M A; HASEEB, A S M A and MASJUKI, H $H$ (2011b). Effect of different corrosion inhibitors on the corrosion of cast iron in palm biodiesel. Fuel Processing Technology, 92: 2154-2159. DOI:10.1016/j. fuproc.2011.06.012.

FAZAL, M A; HASEEB, A S M A and MASJUKI, H H (2012). Degradation of automotive materials in palm biodiesel. Energy, 40: 76-83. DOI:10.1016/j. energy.2012.02.026.

FAZAL, M A; HASEEB, A S M A and MASJUKI, H $H$ (2013). Corrosion mechanism of copper in palm biodiesel. Corrosion Science, 67: 50-59. DOI:10.1016/j. corsci.2012.10.006.

FERNANDES, D M; MONTES, R H O; ALMEIDA, E S; NASCIMENTO, A N; OLIVEIRA, P V; RICHTER, E M and MUÑOZ, R A A (2013). Storage stability and corrosive character of stabilised biodiesel exposed to carbon and galvanised steels. Fuel, 107: 609-614. DOI:10.1016/j.fuel.2012.11.010.

GELLER, D P; ADAMS, T T; GOODRUM, J W and PENDERGRASS, J (2008). Storage stability of poultry fat and diesel fuel mixtures: specific gravity and viscosity. Fuel, 87: 92-102. DOI:10.1016/j. fuel.2007.03.043.

GRAINAWI, L; JAKAB, M A; WESTBROOK, S R and HUTZLER, S A (2008). Testing for compatibility of steel with biodiesel. SwRI Project, (08.13070). https: / / www.stispfa.org / Portals / 0 / STI\% 20 Final\%20Report_07Apr2008.pdf

HASEEB, A S M A; FAZAL, M A; JAHIRUL, M I and MASJUKI, H H (2011a). Compatibility of automotive materials in biodiesel: a review. Fuel, 90: 922-931. DOI:10.1016/j.fuel.2010.10.042.

HASEEB, A S M A; JUN, T S; FAZAL, M A and MASJUKI, H H (2011b). Degradation of physical 
properties of different elastomers upon exposure to palm biodiesel. Energy, 36: 1814-1819. DOI:10.1016/j. energy.2010.12.023.

HASEEB, A S M A; MASJUKI, H H; ANN, L J and FAZAL, M A (2010a). Corrosion characteristics of copper and leaded bronze in palm biodiesel. Fuel Processing Technology, 91: 329-334. DOI:10.1016/j. fuproc.2009.11.004.

HASEEB, A S M A; MASJUKI, H H; SIANG, C T and FAZAL, M A (2010b). Compatibility of elastomers in palm biodiesel. Renewable Energy, 35: 2356-2361. DOI:10.1016/j.renene.2010.03.011.

HU, E; XU, Y; HU, X; PAN, L and JIANG, S (2012). Corrosion behaviors of metals in biodiesel from rapeseed oil and methanol. Renewable Energy, 37: 371-378. DOI:10.1016/j.renene.2011.07.010.

HU, Z; ZHOU, Y; DENG, J; WU, Z and LI, L (2010). Compatibility of biodiesels and their blends with typical rubbers and copperish metals (No. 2010-010476). SAE Technical Paper. DOI:10.4271/2010-010476 .

ISO 2160:1998 (1998). Petroleum products-corrosiveness to copper-copper strip test. International Organization for Standardization. http:/ / www.iso.org/ iso/iso_catalogue/catalogue_tc/catalogue_detail. htm?csnumber $=27552$

KALAM, M and MASJUKI, H (2002). Biodiesel from palmoil - an analysis of its properties and potential. Biomass and Bioenergy, 23: 471-479. DOI:10.1016/ S0961-9534(02)00085-5.

KAUL, S; SAXENA, R C; KUMAR, A; NEGI, M S; BHATNAGAR, A K; GOYAL, H B and GUPTA, A K (2007). Corrosion behavior of biodiesel from seed oils of Indian origin on diesel engine parts. Fuel Processing Technology, 88: 303-307. DOI:10.1016/j. fuproc.2006.10.011.

LANE, J (2013). Biofuels mandates around the world: 2014. Biofuels Digest. http://www.biofuelsdigest. com / bdigest / 2013 / 12 / 31 / biofuels-mandatesaround-the-world-2014/

LIMA, S N M S (2013). Brazil government weighs mixing more biodiesel with diesel fuel. http:// www.bloomberg.com/news / articles / 2013-10-30/ brazil-government-weighs-mixing-more-biodieselwith-diesel-fuel

LINHARES, F N; CORRÊA, H L; KHALIL, C N; AMORIM MOREIRA LEITE, M C and GUIMARÃES FURTADO, C R (2013). Study of the compatibility of nitrile rubber with Brazilian biodiesel. Energy, 49: 102-106. DOI:10.1016/j.energy.2012.10.040.

LIU, J and FANG, Y K (2009). Effect of dissolved oxygen on corrosion of 20r steel in bio-diesel reactor raw mixture [J]. Corrosion \& Protection, 10: 009. http: / / en.cnki.com.cn / Article_en/CJFDTOTALFSYF200910009.htm

MARU, M M; LUCCHESE, M M; LEGNANI, C; QUIRINO, W G; BALBO, A; ARANHA, I B; COSTA, L T; VILANI, C; DE SENA, L Á; DAMASCENO, J C; DOS SANTOS CRUZ, T; LIDÍZIO, L R; FERREIRA E SILVA, R; JORIO, A and ACHETE, C A (2009). Biodiesel compatibility with carbon steel and HDPE parts. Fuel Processing Technology, 90: 1175-1182. DOI:10.1016/j.fuproc.2009.05.014.

MAZZOLENI, C; KUHNS, H D; MOOSMÜLLER, H; WITT, J; NUSSBAUM, N J; OLIVER CHANG; M C O; PARTHASARATHY, G; NATHAGOUNDENPALAYAM, S K K; NIKOLICH, G and WATSON, J G (2007). A case study of real-world tailpipe emissions for school buses using a $20 \%$ biodiesel blend. Science of the Total Environment, 385: 146-159. DOI:10.1016/j. scitotenv.2007.06.018.

MCCORMICK, R L and TERRY, B (2006). Impact of biodiesel blends on fuel system component durability (No. 2006-01-3279). SAE Technical Paper. DOI:10.4271/2006-01-3279.

MEENAKSHI, $\mathrm{H}$ N; ANISHA, A; SHYAMALA, R; SARATHA, R and PAPAVINASAM, S (2011). Corrosivity of Pongamia pinnata biodiesel-diesel blends on a few industrial metals. Proc. of the NACE Corrosion Conference (CORROSION'11). http:// www.researchgate.net / publication / 241562641_ Corrosivity_of_Pongamia_pinnata_Biodiesel_iesel_Blends_on_a_Few_Industrial_Metals

MEENAKSHI, H; PARAMESWARAN; ANISHA, A and KRISHNAMURTHY S R (2013). A comparison of corrosion behavior of copper and its alloy in Pongamia pinnata oil at different conditions. J. Energy. DOI:10.1155/2013/932976.

MICALLEF, G (2009). Elastomer selection for biofuel requires a systems approach. Sealing Technology, 1: 7-10. DOI:10.1016/S1350-4789(09)70022-4.

MOFIJUR, M; MASJUKI, H H; KALAM, M A; ATABANI, A E; SHAHABUDDIN, M; PALASH, S M and HAZRAT, M A (2013). Effect of biodiesel from various feedstocks on combustion characteristics, engine durability and materials compatibility: a review. Renewable and Sustainable Energy Reviews, 28: 441-455. DOI:10.1016/j.rser.2013.07.051. 
NG, J H; NG, H K and GAN, S (2010). Advances in biodiesel fuel for application in compression ignition engines. Clean Technologies and Environmental Policy, 12: 459-493. DOI:10.1007/s10098-009-0268-6.

NOROUZI, S; ESLAMI, F; WYSZYNSKI, M L and TSOLAKIS, A (2012). Corrosion effects of RME in blends with ULSD on aluminium and copper. Fuel Processing Technology, 104: 204-210. DOI:10.1016/j. fuproc.2012.05.016.

PETRASH, D R (2002). Oilfield corrosion inhibitors and their effects on elastomeric seals. NACE International Publication. http://documents. $\mathrm{mx} /$ documents / nace-1g286-oilfield-corrosioninhibitors-and-their-effects-on-elastomeric-seals. html

RASHID, U; ANWAR, F and KNOTHE, G (2009). Evaluation of biodiesel obtained from cottonseed oil. Fuel Processing Technology, 90: 1157-1163. DOI:10.1016/j.fuproc.2009.05.016.

RODRIGUES, RA and ACCARINI, J H (2009). Brazil's Biodiesel Program. Ministry of External Relations, Government of Brazil. http:/ / www. dc. mre. gov. br/imagens-e-textos/Biocombustiveis-09ingprogra mabrasileirobiodiesel. pdf

SARIN, A; ARORA, R; SINGH, N P; SARIN, R; SHARMA, M and MALHOTRA, R K (2009a). Effect of metal contaminants and antioxidants on the oxidation stability of the methyl ester of Pongamia. J. Amer. Oil Chem. Soc., 87: 567-572. DOI:10.1007/ s11746-009-1530-0.

SARIN, A; ARORA, R; SINGH, N P; SHARMA, M and MALHOTRA, R K (2009b). Influence of metal contaminants on oxidation stability of Jatropha biodiesel. Energy, 34: 1271-1275. DOI:10.1016/j. energy.2009.05.018.

SGROI, M; BOLLITO, G; SARACCO, G and SPECCHIA, S (2005). BIOFEAT: biodiesel fuel processor for a vehicle fuel cell auxiliary power unit: study of the feed system. J. Power Sources, 149: 8-14. DOI:10.1016/j.jpowsour.2004.12.059.

SINGH, B; KORSTAD, J and SHARMA, Y C (2012). A critical review on corrosion of compression ignition (CI) engine parts by biodiesel and biodiesel blends and its inhibition. Renewable and Sustainable Energy Reviews, 16: 3401-3408. DOI:10.1016/j. rser.2012.02.042.

SORATE, K and BHALE, P (2013). Impact of biodiesel on fuel system materials durability. J. Scientific $\mathcal{E}$ Industrial Research, 72: 48-57. http: / / nopr.niscair.res. in/handle/123456789/15552
THOMAS, E W; FULLER, R E and TERAUCHI, K (2007). Fluoroelastomer compatibility with biodiesel fuels (No. 2007-01-4061). SAE Technical Paper. DOI:10.4271/2007-01-4061.

TRAKARNPRUK, $\mathrm{W}$ and PORNTANGJTLIKIT, $\mathrm{S}$ (2008). Palm oil biodiesel synthesized with potassium loaded calcined hydrotalcite and effect of biodiesel blend on elastomer properties. Renewable Energy, 33: 1558-1563. DOI:10.1016/j.renene.2007.08.003.

TSUCHIYA, T; SHIOTANI, H; GOTO, S; SUGIYAMA, $G$ and MAEDA, A (2006). Japanese standards for diesel fuel containing 5\% FAME: investigation of acid generation in FAME blended diesel fuels and its impact on corrosion (No. 2006-01-3303). SAE Technical Paper. DOI:10.4271/2006-01-3303.

VAN GERPEN, J H; PETERSON, $\mathrm{C}$ L and GOERING, C E (2007). Biodiesel: An Alternative Fuel for Compression Ignition Engines. American Society of Agricultural and Biological Engineers. http:// web.cals.uidaho.edu / biodiesel / files / 2013/08 / VanGerpen-Peterson-Goering1.pdf

YAMAGATA, H (2005). The Science and Technology of Materials in Automotive Engines. https://books. google.com.my / books?hl=en\&lr=\&id=7rekAgAAQ $\mathrm{BAJ} \& \mathrm{o}=\mathrm{fnd} \& \mathrm{pg}=\mathrm{PP} 1 \& \mathrm{dq}=\mathrm{The}+$ science + and + tech nology+of + materials+in+automotive+engines\&ots =qyZnd2P9HJ\&sig=jAX0GAWII-opS49EczVQrV2aec\&redir_esc $=\mathrm{y} \# \mathrm{v}=$ onepage $\& \mathrm{q}=\mathrm{The} \% 20$ science $\% 20$ and $\% 20$ technology $\% 20$ of $\% 20$ materials $\% 20 \mathrm{in} \% 20$ automotive $\%$ 20engines\& $\mathrm{f}=$ false

ZAINAL, H (2014). B7 biodiesel to be launched to replace B5 at petrol stations from Nov. 1. The Star. http://www.thestar.com.my/news/ nation / 2014/10/29/b7-biodiesel-to-be-launchedlower-emission-fuel-to-replace-b5-at-petrol-stationnation-nov-1/

ZHANG, X; LI, L; WU, Z and HU, Z (2009). Material compatibilities of biodiesels with elastomers, metals and plastics in a diesel engine (No. 2009-01-2799). SAE Technical Paper.

ZULETA,EC;BAENA, L;RIOS, LAand CALDERÓN, $\mathrm{J} A$ (2012). The oxidative stability of biodiesel and its impact on the deterioration of metallic and polymeric materials: a review. J. Brazilian Chemical Society, 23: 2159-2175. DOI:10.1590/S0103-50532012001200004. 